Original Article

\title{
PREVALENCE AND CORRELATION OF CONTRACEPTIVE USE AMONG FEMALES IN JEDDAH, SAUDI ARABIA
}

\author{
ALAA BAGALAGEL ${ }^{1}$ \\ 1Pharmacy Practice Department, Faculty of Pharmacy, King Abdulaziz University, Jeddah 21589, Saudi Arabia \\ Email: abagalagel@kau.edu.sa
}

Received: 30 Apr 2020, Revised and Accepted: 12 Jun 2020

\begin{abstract}
Objective: The purpose of this study was to examine the prevalence of contraceptive use and the correlates of contraceptive use among females in Jeddah, Saudi Arabia. Moreover, it aimed to evaluate the knowledge about contraceptives and their use.

Methods: The study was a community-based, cross-sectional descriptive survey conducted in Saudi Arabia from 28 September 2015 to 10 December 2015.

Results: The current study showed that the most commonly used contraceptives were intrauterine devices (IUD's) (29.1\%), followed by male condoms (27.7\%). Most of the participants, $47.6 \%$, started using a contraceptive after giving birth to their first child. Nearby, $60 \%$ of participants used contraceptives without a prescription or medical advice. Only $13.7 \%$ of participants sought the advice of a pharmacist about which contraceptive they should use, while $30.6 \%$ and $24.2 \%$ of participants choose their contraceptive based on general knowledge and relatives' experiences, respectively. Around $80 \%$ of participants stated that they did not have any problem while buying contraceptives from pharmacies without a prescription.
\end{abstract}

Conclusion: Pharmacists and medical health providers need to fill this gap to improve the use of contraceptives.

Keywords: Contraceptives, Prevalence, Saudi Arabia

(C) 2020 The Authors. Published by Innovare Academic Sciences Pvt Ltd. This is an open access article under the CC BY license (http://creativecommons.org/licenses/by/4.0/) DOI: http://dx.doi.org/10.22159/ijpps.2020v12i8.38100. Journal homepage: https://innovareacademics.in/journals/index.php/ijpps.

\section{INTRODUCTION}

Millions of women around the world have used contraceptives since their debut in 1957. Contraceptives remain the most prescribed medications for women ages 18-44 [1]. They enable women to control their reproduction and, thereby, other aspects of their lives, such as career and family [2].

Over the past $40 \mathrm{y}$, there have been significant advances in their development [3]. However, current policies and health care practices in some countries are based on scientific studies of contraceptive products that are no longer widely used [4]. Because country situations and program environments vary so greatly, it is inappropriate to set firm international guidelines on criteria for contraceptive use [5]. It is expected that national programs will use these recommendations for updating or developing their own contraceptive eligibility guidelines according to national health policies, needs, priorities and resources, while reflecting upon local values and preferences [6].

There are many contraceptive methods. Some of the most commonly used are: intrauterine devices (IUDs), long-acting and reversible contraceptive devices [7], an emergency contraceptive pill (ECP) taken orally after unprotected sex [8], and Levonorgestrel (LNG) also taken post-coitally "after intercourse", a method of emergency contraception (EC) that arrests or delays ovulation [9-11], and, the vaginal ring, which administers the delivery of selective progesterone receptor modulators (SPRMs) into the body [12]

Besides the methods listed above, a less complex method is the condom. Scientifically recommended as potential products for preventing infections attributable to human immunodeficiency viruses (HIV), condoms act as a barrier to keep sperm from entering the uterus [13]. Another wearable contraceptive choice is the patch which provides the systemic delivery of steroid hormones by transdermal technology using patches that contain estrogen or estrogen plus a progestin that has been successfully used for contraception [14]. Yet another product of choice, but more invasive, is the Implantable birth control rod, a matchstick-sized, flexible plastic, the surgically inserted device that releases progestin [15].
Female patients requiring treatment for pulmonary arterial hypertension (PAH) are advised to avoid pregnancy because of the high associated mortality rate [16], and oral contraception is one of the main methods of preventing pregnancy. They may be combined, or progesterone alone, the combined oral contraceptive pills (COCs) contain different combinations of the synthetic estrogens and are given to interfere with ovulation. In contrast, Progestin-only pills (POPs) may interfere with ovulation or with sperm function by thickening cervical mucus, making it difficult for sperm to move [17]. In most countries, various types of pills are available, and studies have shown an increased risk of venous thromboembolism with the use of combined oral contraceptives [18-20]. This risk differs according to a type of progestogen and decreases with both duration of use and decreasing estrogen dose [21, 22].

A progestogen-only injectable contraceptive is also available that acts for a long time and involves an injection of a progestin as a depot. Progestogen-only injectable contraception is highly effective, reversible and safe for most women [23].

A less scientific alternative is the natural method. This involves recording the fertile and infertile times of a woman's cycle to plan when to avoid pregnancy [24].

Using contraceptives in recent years, an integral part of a healthy lifestyle remains one of the most significant challenges for human beings; this challenge is the need to expand the use of contraceptives in Saudi Arabia and the world in controlled ways and to seek to address the effects of overpopulation. The who forecasts that the world's population, at present, which is about six billion people and is estimated to rise until it reaches almost eight billion by 2025 , more than nine billion in 2050 [25].

The present study aims to determine the extent of use of contraceptives between people in Saudi Arabia. Moreover, its aim is to evaluate the knowledge about contraceptives and their use among the population as well as the intervention and effective communication between pharmacists and patients. 


\section{MATERIALS AND METHODS}

\section{Methods}

The study was a community-based, cross-sectional survey conducted in Jeddah, Saudi from 28 September 2015 to 10 December 2015. The current study was carried out on 618 adult participants ages 13-50 y for an assumed prevalence of contraceptives. Each participant was asked through direct contact to complete a structured self-administered questionnaire, available in Arabic and English. Pilot questionnaires were distributed for validation. Population samples were selected randomly through the distribution of the questionnaires through four high schools, one university, hospitals and an electronic survey. The collected data were pooled and analyzed by description.

A structured questionnaire (table 1) consisted of three sections (i) the socioeconomic and demographic characteristics of the participant; (ii) participants' knowledge and attitudes regarding contraceptives use; and (iii) the intervention and effective communication between physician, pharmacist and patients.

Table 1: Survey questionnaire

\section{Section (I)}

How old are you?

What is your nationality?

What is your level of education?

What is your occupation?

What is your income?

Are you a smoker?

What is your skin color?

What is your husband's educational level?

What is your husband's occupation?

Section (II)

Do you have general information about the menstrual cycle and what the best time would be for intercourse in order to conceive or avoid pregnancy?

Do you have any general information about the different ways to prevent pregnancy or do you just know one thing?

What do you think about contraception, in general?

If you answered that it is not good, what is the reason?

Do you or have you used contraceptives before?

If you answered "yes", what are the types?

At what age did you start to use contraceptives?

Do you use contraceptives after having a child?

What is the reason for contraceptive use?

Do you have any chronic diseases?

If you answered "yes", which?

Do you take any other drugs with contraceptives?

If you answered "yes", what are these drugs?

Are you fully aware of the side effects of contraceptives?

During your use of contraceptives, did any side effects appear?

If you answered "yes", what were they?

Did any psychological changes occur while using contraceptives?

Did you stop using immediately if you saw one of the following symptoms?

- Headaches accompanied by nausea, vomiting and blurred vision

- Obesity

- Continuously feeling nervous

Did the side effects persist after you stopped contraceptives?

If you answered "yes", did you consult a doctor?

Did the pharmacist refuse to allow you to buy contraceptive pills without a prescription?

Did you get pregnant while you were on a contraceptive?

Did you try to change the type?

If you answered "yes", what is the reason?

What is the appropriate time to use contraception?

Section (III)

Did you consult a physician before using a contraceptive?

If you have not consulted a doctor, what was your source and choice of contraceptive?

Did your doctor ask you to do some tests?

If you answered "yes", which one(s)?

Did your doctor ask if you suffer from depression or psychological issues?

Did you tell your doctor if you use some form of contraceptive?

\section{RESULTS}

A questionnaire was distributed in the Jeddah community, 618 women were included in the study. The current study showed that the most commonly used contraceptive is an IUD, and intrauterine device (fig. 1).

We found that $47.6 \%$ of participants started to use contraceptives after giving birth to their first child, and $64.8 \%$ decided to use them due to family planning (fig. 2). Furthermore, around $60 \%$ of the participants were using contraceptives without prescriptions. Their source for information about contraceptives was obtained mainly from general information $(30.6 \%)$, and $24.2 \%$ of participants used relatives for advice on how to use contraceptives (fig. 3). Sociodemographics of participants and its relation to the type of contraceptive use is shown in table 2. Furthermore, knowledge and attitude about contraceptives are stated in table 3 . The role of physicians and pharmacists were obtained from participants responses, as presented in table 4 


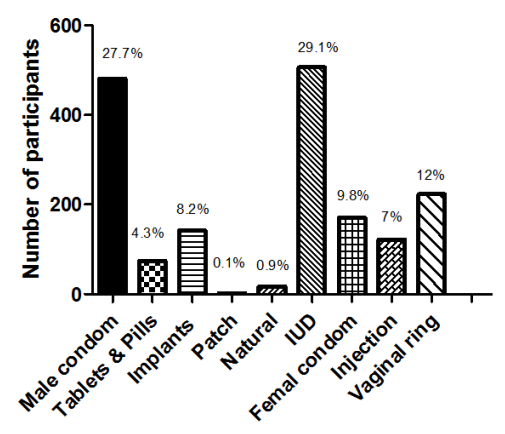

Fig. 1: Prevalence of contraceptive use
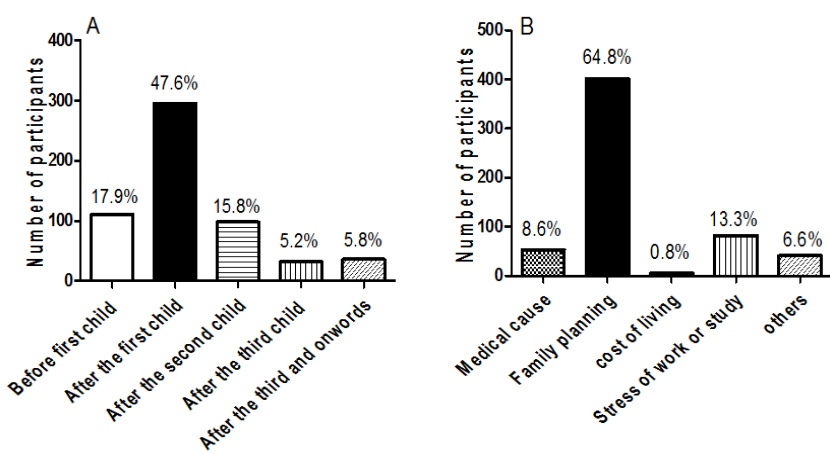

Fig. 2: Timing and source of contraceptive use
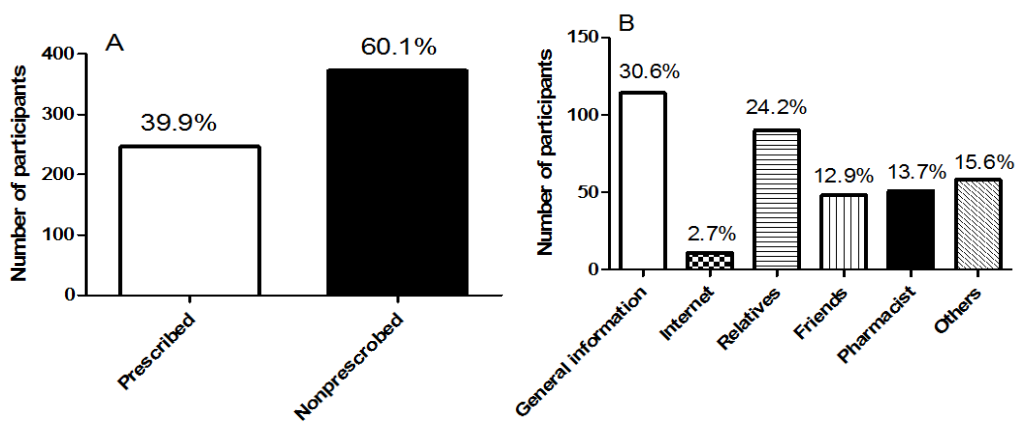

Fig. 3: Prescribed contraceptives and source of information

Table 2: Socio-demographics of participants and its relation to the type of contraceptive use

\begin{tabular}{|c|c|c|c|c|c|c|c|c|c|}
\hline \multicolumn{10}{|c|}{ Type of contraceptives number (\%) } \\
\hline & $\begin{array}{l}\text { Male } \\
\text { condom }\end{array}$ & Tablets & Implant & Patch & Natural & IUD & $\begin{array}{l}\text { Female } \\
\text { condom }\end{array}$ & Injection & Ring \\
\hline $\begin{array}{l}\text { Total: } 618 \\
(100 \%) \\
\text { Age: }\end{array}$ & $\begin{array}{l}482 \\
(77.99)\end{array}$ & $534(86.4)$ & $\begin{array}{l}143 \\
(23.13)\end{array}$ & $\begin{array}{l}403 \\
(65.21)\end{array}$ & $\begin{array}{l}421 \\
(68.12)\end{array}$ & $\begin{array}{l}507 \\
(82.03)\end{array}$ & $\begin{array}{l}172 \\
(27.83)\end{array}$ & $\begin{array}{l}290 \\
(46.92)\end{array}$ & $\begin{array}{l}224 \\
(36.24)\end{array}$ \\
\hline$-13-18$ & $1(0.20)$ & $2(0.37)$ & 0 & $2(0.49)$ & $1(0.23)$ & $2(0.39)$ & $1(0.58)$ & 0 & 0 \\
\hline$-19-30$ & $98(20.33)$ & 117 & $62(43.35)$ & $65(16.1)$ & 89 & 102 & $42(24.41)$ & $57(19.65)$ & $53(23.66)$ \\
\hline$-31-40$ & $177(36.72)$ & $(21.92)$ & $53(37)$ & 153 & $(21.14) 154$ & $(20.11)$ & $56(32.55)$ & $116(40)$ & 77 (34.37) \\
\hline$->40$ & $7(18.04)$ & $\begin{array}{l}196 \\
(36.70) \\
99(18.5)\end{array}$ & $25(17.48)$ & $\begin{array}{l}(37.96) \\
69(17.12)\end{array}$ & $\begin{array}{l}(36.57) 72 \\
(17.10)\end{array}$ & $\begin{array}{l}187(36.88) \\
102 \\
(20.11)\end{array}$ & $27(15.69)$ & $49(16.89)$ & $41(18.30)$ \\
\hline $\begin{array}{l}\text { Education } \\
\text { level: }\end{array}$ & 96 (19.9) & 77 (14.41) & $20(13.98)$ & 75 (18.61) & $71(16.86)$ & 104 & 28 (16.27) & $54(18.62)$ & $38(16.96)$ \\
\hline $\begin{array}{l}\text {-low } \\
\text {-moderate } \\
\text {-high }\end{array}$ & $\begin{array}{l}312(64.73) \\
68(14.10)\end{array}$ & $\begin{array}{l}241 \\
(45.13) \\
74(13.85)\end{array}$ & $\begin{array}{l}70(48.95) \\
29(20.27)\end{array}$ & $\begin{array}{l}223 \\
(55.33) \\
55(13.64)\end{array}$ & $\begin{array}{l}232 \\
(55.10) \\
60(14.25)\end{array}$ & $\begin{array}{l}(20.51) \\
273 \\
(53.84) \\
59(11.63)\end{array}$ & $\begin{array}{l}89(51.74) \\
29(16.86)\end{array}$ & $\begin{array}{l}157 \\
(54.13) \\
47(16.20)\end{array}$ & $\begin{array}{l}109 \\
(48.66) \\
38(16.96)\end{array}$ \\
\hline
\end{tabular}




\begin{tabular}{|c|c|c|c|c|c|c|c|c|c|}
\hline \multicolumn{10}{|l|}{ Work: } \\
\hline -Work & 174 (36.09) & 196 & $73(51.04)$ & 152 & 164 & $190(37.4)$ & $76(44.18)$ & 122 & $88(39.2)$ \\
\hline \multirow[t]{3}{*}{-Don't work } & $191(29.62)$ & $(36.70)$ & $47(32.86)$ & (37.71) & (38.95) & $205(40.4)$ & $64(37.20)$ & $(42.06)$ & 85 (37.90) \\
\hline & & 221 & & 154 & 167 & & & 102 & \\
\hline & & (41.38) & & (38.21) & $(39.66)$ & & & (35.17) & \\
\hline \multicolumn{10}{|l|}{ Husband's' } \\
\hline work: & $10(2.07)$ & $256(47.9)$ & $1(0.69)$ & $52(12.9)$ & $2(0.47)$ & $43(8.48)$ & 0 & $17(5.86)$ & $4(1.78)$ \\
\hline -Work & 0 & $23(4.3)$ & 0 & $6(1.48)$ & 0 & $5(0.98)$ & 0 & 0 & 0 \\
\hline -Don't work & $1(0.2)$ & $28(5.24)$ & 0 & $6(1.48)$ & 0 & $4(0.78)$ & 0 & 0 & 0 \\
\hline Social level: & $92(19.08)$ & 116 & $23(16.08)$ & $70(17.36)$ & $71(16.86)$ & 100 & $20(11.62)$ & $42(14.48)$ & 30 (13.39) \\
\hline -Low & $157(32.57)$ & (21.72) & 35 (24.47) & 136 & 138 & (19.72) & $58(33.72)$ & 100 & 75 (33.48) \\
\hline -Mid & $145(30.08)$ & 163 & $52(36.36)$ & (33.74) & $(32.77)$ & 160 & $56(32.55)$ & $(34.48)$ & 107 \\
\hline \multirow[t]{3}{*}{-High } & & $(30.52)$ & & 132 & 137 & (31.55) & & 130 & $(47.76)$ \\
\hline & & 156 & & $(32.75)$ & (32.54) & 153 & & $(44.82)$ & \\
\hline & & (29.21) & & & & (30.17) & & & \\
\hline \multicolumn{10}{|l|}{ Skin color: } \\
\hline -White & $171(35.47)$ & 180 & $53(37.06)$ & 138 & 146 & 170 & $63(36.62)$ & 100 & 85 (37.94) \\
\hline -Brown & $18(3.73)$ & $(33.70)$ & $6(4.19)$ & (34.24) & $(34.67)$ & (33.53) & $9(5.23)$ & $(34.48)$ & $10(4.46)$ \\
\hline \multirow[t]{3}{*}{-Wheaten } & $261(54.14)$ & $28(5.24)$ & $84(58.74)$ & $16(3.97)$ & $18(4.27)$ & $25(4.93)$ & $88(51.16)$ & $12(4.13)$ & 113 \\
\hline & & 286 & & 246 & 225 & 303 & & 173 & $(50.44)$ \\
\hline & & (53.55) & & (61.04) & (53.44) & (59.76) & & (59.65) & \\
\hline \multicolumn{10}{|l|}{ Smoking: } \\
\hline -Smoke & $1(0.2)$ & $56(10.4)$ & 0 & $13(3.22$ & 0 & $8(1.57)$ & 0 & $15(5.17)$ & $1(0.44)$ \\
\hline -Don't smoke & $9(1.86)$ & $251(47)$ & $1(0.69)$ & $51(12.6)$ & $2(0.47)$ & 47 (9.27) & 0 & $15(5.17)$ & $3(1.33)$ \\
\hline
\end{tabular}

Table 3: Knowledge and attitude about contraceptives

\begin{tabular}{|c|c|}
\hline Knowledge & Response, number (\%) \\
\hline Consult a physician before using & $\begin{array}{ll}\text { - } & \text { Yes } 447(72.21 \%) \\
\text { - } & \text { No } 128(20.68 \%)\end{array}$ \\
\hline Knowing about side effects & $\begin{array}{ll}\text { - } & \text { Yes } 328(52.99 \%) \\
\text { - } & \text { No } 20(3.23 \%) \\
\text { - } & \text { Not well } 242(39.10 \%)\end{array}$ \\
\hline Knowing about contraceptive types & $\begin{array}{ll}\text { - } & \text { Tablets and pills } 437(70.60 \%) \\
\text { - } & \text { Intrauterine device } 70(11.31 \%) \\
\text { - } & \text { Hormone patch } 16(2.58 \%) \\
\text { - } & \text { Vaginal ring } 4(0.65 \%) \\
\text { - } & \text { Cultivation under the skin } 1(0.16 \%) \\
\text { - } & \text { Female medical condoms } 1(0.16 \%) \\
\text { - } & \text { Injection } 3(0.48 \%) \\
\text { - } & \text { Others } 19(3.07 \%)\end{array}$ \\
\hline Getting pregnant while using & $\begin{array}{l}\text { - } \quad \text { Yes } 86(13.89 \%) \\
\text { - } \quad \text { No } 467(75.44 \%)\end{array}$ \\
\hline trying to change the type & $\begin{array}{l}\text { - } \quad \text { Yes } 301(48.63 \%) \\
\text { - } \quad \text { No } 244(39.42 \%)\end{array}$ \\
\hline If you answered "yes", what is the reason (for changing) & $\begin{array}{ll}\text { - } & \text { Got pregnant } 58(9.37 \%) \\
\text { - } & \text { Nausea } 41(6.62 \%) \\
\text { - } & \text { Discomfort } 167(26.98 \%) \\
\text { - } & \text { Fatty bags } 12(1.94 \%) \\
\text { - } & \text { Other } 98(15.83 \%)\end{array}$ \\
\hline
\end{tabular}

Table 4: Role of physicians and pharmacists

\begin{tabular}{ll}
\hline Role & Response, number (\%) \\
\hline Doctor asked to do some investigations & $\bullet$ Yes $198(31.99 \%)$ \\
The type of investigations & $\bullet$ No $320(51.70 \%)$ \\
& $\bullet$ Fat level $30(4.85 \%)$ \\
& $\bullet$ Liver function $8(1.29 \%)$ \\
Doctor asked about depression or psychological issues & $\bullet$ Blood sugar $13(2.10 \%)$ \\
& $\bullet$ Pregnancy tests $73(11.79 \%)$ \\
Finding refusal from the pharmacist (being denied) while buying without a & $\bullet$ Ido not know $49(7.92 \%)$ \\
prescription & $\bullet$ Yes $82(13.25 \%)$ \\
\hline
\end{tabular}




\section{DISCUSSION}

Since contraceptives first became available in the 1960s, they have been in extensive use throughout the world. Convenient and useful, birth control pills are also beneficial in treating menstrual disorders [26]. Effective contraception is a significant factor in a woman's ability to plan her pregnancies, that is to achieve desired birth spacing and family size [27], changes in contraceptive method choice and use have not decreased the overall proportion of pregnancies that are unintended due to compositional changes in race, marital state, age, place of residence, education and income [28]

Most women in the US used pills (51\%), with approximately $50 \%$ of users in the age range of $15-19,40 \%$ being $20-24$ y of age, and $10 \%$ at age 40-44 y [29]. There were changes in current method choice by race and education; pill use decreased among Black women to $18 \%$, but still higher than for White women. Three times as many women with a bachelor's degree or higher relied on the pill $(35 \%)$ [30]. And, $77.4 \%$ of women with public insurance, incomes above $5,500 \$ /$ month and who lived in nonmetropolitan areas were much more likely to use the pill as a contraceptive method compared with $22.6 \%$ without insurance; and, those living in central cities were more likely to rely on the condom [31]

Oral contraceptives (OCs) have been available in Canada for over $50 \mathrm{y}$ until now, with decreasing estrogen doses, new progestins, and different dosing regimens. However, pill use in Canada is a second choice (36\%) [32]. Among oral contraceptive users (36\%) reported smoking either daily or occasionally. Almost all (99\%) OC users took combined formulations containing ethinyl estradiol (EE) and progestin. Others took formulations containing 30 or more mcg of EE [33].

OC use decreased with age, $60.4 \%$ of women aged $15-30$ reported taking OCs, 36.6\% women aged 31-49 [34]. Oral contraceptives use was significantly higher for women with post-secondary education (44\%) than for those for women who did not have this level of schooling, and finally, among those who reported having prescription drug insurance coverage $(57.2 \%)$ more than women who had no such benefits [35]. The percentage of White women using oral contraceptives was markedly lower $(19 \%)$ compared with Black women who said they were not on the pill (30\%) [36]. The World Health Organization (WHO) considers the prevalence of contraceptive usage among Saudi society in Riyadh city as one of the determinants of women's health and empowerment in that society. Some societies use contraceptives to regulate pregnancies and in birth spacing. Religious issues may also play a significant role in determining how couples view such issues as contraception. Certain religions do not permit the use of contraception, and children from religious families may not even know the essentials on birth control methods [22]. The current study shows that the preferable type of contraception in Riyadh is the pill (71.7\%). Use of different types of contraception according to age in the current study revealed that young females preferred the use of the vaginal ring and older females preferred either the IUD or pills; $21.1 \%$ aged $17-25 \mathrm{y}$ old; $40.9 \%$ of pill users aged $26-35$ y old; and $33 \%$ aged $36-50$ y [37]

Education on various methods of birth control, as well as the distribution of contraceptives, is a significant concern for the international community, women who have a bachelor's degree or higher are $78.1 \%$ [38]. The current study illustrates that the attitude of females towards contraception was affected by their working status, finding it was better among housewives, more than half were working (52.1\%); and only $3.9 \%$ of participants had an income of less than 3,000 riyals/month, while $44.1 \%$ had an income higher than 13,000 riyals/month. The majority of the sample was married (94.4\%) [39]. Only $4.3 \%$ of Saudi Arabian women used pills as a contraceptive method because they think the other methods provide more control than pills. Saudi women have purchased over six million birth control pills costing SR 108 million in 2014. Women usually buy certain brands, with the Gynera brand being in the lead with sales of SR 34.2 million, followed by Yasmin at SR 27.2 million, Marvelon at SR 23 million, and Neo Sampoon at SR 4,600,000 as reported the same year [40].

Preferences for fertility control include family size, the timing of establishing a family, and choice of occupation. Canadians and their health care providers are thus involved in infertility-related decisions that will fundamentally influence individual lives and society as a whole well into the future [41]. Family planning decisions affect and are influenced by emotional health, sexual attitudes and behaviors, gender equity, the quality of relationships, and respect between men and women [42]. Condom use was higher among all age-groups (99\%) with the exception of men aged 45-49. Condom use was more common among males than females [43]. Condom use among White men was $60 \%$ but still higher in Black men. Non-educated men were slightly higher by $55.5 \%$ than those who are educated at $44.5 \%$ [44]. The statistics showed Americans using condoms as a second choice (30\%); overall, $46 \%$ of men aged 15-44 used condoms, and 54\% were not. The percentage using, and the type of method used vary significantly by age [45]. A more significant percentage of White men $(66 \%)$ were using condoms compared with Black men at 54\% [46]. Research showed that many people in Riyadh continue to have fears and misconceptions about modern contraceptives. Condom use in Riyadh is low (1\%) [47]. Approximately $27.7 \%$ of the Saudi Arabian population used [male] condoms, almost all condom users were employed $(87.5 \%)$ and those above $40 \mathrm{y}$ of age (51\%) higher than for younger individuals.

An Intrauterine contraceptive device (IUD) is a T-shaped device containing a copper thread or cylinders which is placed in the uterus by a health care provider. The IUD releases copper ions which immobilize the sperm and make inhibit their ability to move around in the womb but do not stop the ovaries from producing an egg each month [48].

An IUD is one of the contraceptive methods commonly used in the USA. The US rate remains significantly higher (9\%) [49] than that in Canada (4.8\%) and European countries. Use of an intrauterine contraceptive device (IUD) is associated with marked reductions in unintended pregnancy among adolescents [50]. In Riyadh, the IUD is a second choice $(20.1 \%)$, according to age, young females preferred the use of vaginal rings and older females preferred either the IUD or pills. The percentage of highly educated women was higher $(66.2 \%)$ The average income of IUD users was more than 13,000 riyals/month [51]. In this research study, we found that the preferred method in Saudi Arabia was the IUD (29.1\%); most having an average income of more than 10,000 riyals/month $(75.5 \%)$.

Younger women from19-30 were less likely to use IUD's, but others ages $31-40$ used them more $(57.1 \%)$ and ages 40 -above $(24.4 \%)$. Most women the IUD having a bachelor's degree (51\%) and employed (53\%). Also, Blacks at (69.3\%) which is much more than Whites [52]

The contraceptive injection is a shot of hormones either in the muscle or under the skin that lasts for one up to 3 mo. It contains hormones, either a progestin alone or progestin and estrogen together that prevents the body from releasing eggs and thickens the mucus at the cervix. The way it works is similar to the pill or the ring, except the user does not have to remember to take it every day or week [53]. Women residing in the US are less likely to use the injection $(3.1 \%)$ [54] then $(1.7 \%)$ for Canadians and women in Riyadh $(0.4 \%)$ [55], respectively. Contraceptive injection is probably not the best choice for those afraid of needles, so many countries do not utilize this method [56]. In Saudi Arabia, 7\% of women used injectable contraceptives, and of this number, $87.5 \%$ were employed and not smokers.

The types of contraceptive devices and methods have increased with the development of the transdermal patch. The efficacy and safety of this method is similar to those of combined oral contraceptives. However, it differs from the pill in the route of hormone delivery and frequency of administration [57]. The contraceptive patch is just as it states, it is a patch that resembles polished plaster and sticks to the skin. The patch is highly effective in preventing unwanted pregnancies by releasing hormones. The hormones, estrogen and progestin, are released continuously, entering the bloodstream through the skin [57]. Approximately $2.7 \%$ of US women had used the transdermal patch. Physicians did not consider combined hormonal contraceptives to be a suitable method for participating women, mainly due to the presence of contraindications or medical conditions [58]. Also, having a low usage rate is Riyadh at $(2.4 \%)$ 
[59] and then in Canada at $1.2 \%$ [60]. In Saudi Arabia, the contraceptive patch is negligible $(0.1 \%)$ because Saudi women depend on other methods and some $(12.5 \%)$ have a chronic disease thus, prohibiting their ability to utilize this contraceptive.

Another device, the implant contraceptive, is placed just below the skin of the upper arm, where it continually releases the hormone progestin in small doses from a reservoir into the bloodstream. The modern contraceptive prevalence rate remains low. It may initially cause a change in bleeding patterns and may cause weight gain, breast and abdominal pain [61]. Yet, the uptake of implants increased slightly from $2.1 \% \%$ to $2.5 \%$ in the US, at the time of this study [62]. It is, however, still low in Canada (1.5\%) [63] and in Riyadh (1.4\%) [64]. In Saudi Arabia, the number of people using an implant contraceptive is $8.2 \%$, their source of method choice based on general information and personal reading.

Similar to the implant, a contraceptive ring is available that also eliminates the need for daily dosing. The contraceptive ring, also known as the vaginal ring, is a bright and flexible ring of polyethylene vinyl acetate that, once inserted into the vagina, slowly releases the hormones progestin and estrogen into the body to stop the ovaries from releasing eggs [39].

It may cause vaginal discharge, discomfort and irritation in the vagina, and weight gain. Because of these problems, the vaginal ring has the lowest rate of use by women in the United States $(1.1 \%)$ [65], Canada (0.6\%) [66] and Riyadh (1.2\%) [67]. Vaginal ring usage is shallow among Saudi Arabian women (12\%) but almost (99.6\%) all having a higher income (more than 10,000 riyals/month).

Contraceptive use and method choice may change over time for various reasons, including the availability of new methods and more considerable societal changes in fertility patterns. For example, the average age at first birth for women in the United States has increased in recent decades, at least partially because of an increase in first births to women aged 35 [68]. This suggests potential changes over time in the use of contraception by age as first births are delayed. Acceptance of and ability to correctly and consistently use this technology may create challenges for future ring-based microbe-cide trials in settings where this technology has not been introduced [69]. Natural Family Planning (NFP) is the ability of individuals and couples to anticipate and attain their desired number of children and the spacing and timing of their births [47] Only $0.6 \%$ of women had never previously used contraceptive methods in the US [70]. If compared with Canadian women, only $0.2 \%$ were in natural family planning [71]. $1.8 \%$ of women in Riyadh did not use contraception medications reported due to medical reasons; so, they depend on natural family planning. Women need methods that provide them with greater control; so, natural family planning is typically reflected by Saudi women (0.9\%) [47]. This study has potential limitations includes inadequate sample size compared to population and lack of enough previous studies in the same geographical region.

\section{CONCLUSION}

Pharmacists and medical health providers have to fill the gap to improve the use of contraceptives. Government, policymakers, decision-makers and other stakeholders should intensify education on the use of contraceptives.

\section{FUNDING}

Nil

\section{AUTHORS CONTRIBUTIONS}

Alaa Bagalagel write the final manuscript and supervised the findings of this work.

\section{CONFLICTS OF INTERESTS}

Declared none

\section{REFERENCES}

1. Lutalo T, Musoke R, Kong X, Makumbi F, Serwadda D, Nalugoda F. Effects of hormonal contraceptive use on HIV acquisition and transmission among HIV-discordant couples. AIDS 2013;1:2734.

2. Westhoff C. A highly effective contraceptive option with proven long-term safety. Contraception 2003;68:75-87.

3. Segall Gutierrez P, Taylor D, Liu X, Stanzcyk F, Azen S, Mishell Jr. Follicular development and ovulation in extremely obese women receiving depo medroxyprogesterone acetate subcutaneously. Contraception 2010;81:487-95.

4. de Morais TL, Giribela C, Nisenbaum MG, Guerra G, Mello N, Baracat E, et al. Food and drug administration office of surveillance and epidemiology. Combined hormonal contraceptives (CHCs) and the risk of cardiovascular disease endpoints 2011;342:2151-6.

5. Gronich N, Lavi I, Rennert G. Higher risk of venous thrombosis associated with drospirenone-containing oral contraceptives: a population-based cohort study. CMAJ 2011;183:E1319-E1325.

6. Stegeman BH, de Bastos M, Rosendaal FR. Different combined oral contraceptives and the risk of venous thrombosis: systematic review and network meta-analysis. Br Med J 2013;347:5298.

7. Mohllajee AP, Curtis KM, Flanagan RG, Rinehart W, Gaffield ME, Peterson HB. Keeping up with evidence a new system for WHO's evidence-based family planning guidance. Am J Prev Med 2005;28:483-90.

8. Felix AS, Gaudet MM, Vecchia CL. Intrauterine devices and endometrial cancer risk: a pooled analysis of the epidemiology of endometrial cancer consortium. Int J Cancer 2015;136:E410-22.

9. Hussainy SY, Ghosh A, Taft A, Mazza D, Black KI, Clifford R, et al. Protocol for ACCESS: a qualitative study was exploring barriers and facilitators to accessing the emergency contraceptive pill from community pharmacies in Australia. Br Med J Open 2014;89:31-5.

10. Hatcher RA, Trussell J, Nelson AL. Contraceptive technology. New York: Ardent Media; 2007;80:87-116.

11. Thapa S. A new wave in the quiet revolution in contraceptive use in Nepal: the rise of emergency contraception. Reprod Health 2016;13:49.

12. Jensen JT. Vaginal ring delivery of selective progesterone receptor modulators for contraception. Contraception 2013;87:314-8.

13. Mubyazi GM, Exavery A, Tenu F, Massaga JJ, Rugemalila J, Malebo HM, et al. Determinants of demand for condoms to prevent HIV infections among barmaids and guesthouse workers in two districts, Tanzania. BMC Res Notes 2015;8:630.

14. Wiegratz I, Bassol S, Weisberg E, Mellinger U, Merz M. Effect of a low-dose contraceptive patch on efficacy, bleeding pattern, and safety. Reprod Sci 2014;21:1518-25.

15. Hohmann H. Examining the efficacy, safety, and patient acceptability of the etonogestrel implantable contraceptive. Patient Prefer Adherence 2009;3:205-11.

16. Ghofrani HA, Galie N, Grimminger F, Grünig E, Humbert M, Jing $\mathrm{ZC}$, et al. Riociguat for the treatment of pulmonary arterial hypertension. N Engl J Med 2013;369:330-40.

17. Parkin L, Skegg DC, Wilson M, Herbison GP, Paul C. Oral contraceptives and fatal pulmonary embolism. Lancet 2000;355:2133-4.

18. Vandenbroucke JP, Koster T, Briët E, Reitsma PH, Bertina $\mathrm{RM}$, Rosendaal FR. Increased risk of venous thrombosis in oralcontraceptive users who are carriers of factor $\mathrm{V}$ leiden mutation. Lancet 1994;344:1453-7.

19. Thorogood M, Mann J, Murphy M, Vessey M. Risk factors for fatal venous thromboembolism in young women a case-control study. Int J Epidemiol 1992;21:48-52.

20. Farley TM, Meirik O. Effect of different progestogens in low estrogen oral contraceptives on the venous thromboembolic disease. Lancet 1995;346:1582-8.

21. Westhoff C. Depot-medroxyprogesterone acetate injection (Depo-Provera ${ }^{\circledR}$ ): a highly effective contraceptive option with proven long-term safety. Contraception 2003;68:75-87.

22. Shukla A, Jamwal R, Bala K. Adverse effect of combined oral contraceptive pills. Asian J Pharm Clin Res 2017;10:17-21.

23. Halpern V, Combes SL, Dorflinger LJ, Weiner DH. Pharmacokinetics of subcutaneous depot 
medroxyprogesterone acetate injected in the upper arm Contraception 2014;89:31-5.

24. Planas ME, García PJ, Bustelo M, Carcamo CP, Martinez S, Nopo $\mathrm{H}$, et al. Effects of ethnic attributes on the quality of family planning services in lima, peru: a randomized crossover trial. PLOS One 2015;10:121-57.

25. Tuppin P, de Roquefeuil L, Weill A, Ricordeau P, Merliere Y. French national health insurance information system and the permanent beneficiaries sample. Rev Epidemiol Sante Publique 2010;58:286-90.

26. Potter FJ, Iannacchione VG, Mosher WD, Mason RE, Kavee JD. Sample design, sampling weights, imputation, and variance estimation. National Center for Health Statistics. Vital Health Stat 1998;2:1-63.

27. Mosher WD, Jones J. Use of contraception in the world. National Center for Health Statistics. Vital Health Stat 2010;23:554-5.

28. Finer LB, Henshaw SK. Disparities in rates of unintended pregnancy in the United States. Perspect Sex Reprod Health 2006;38:90-6.

29. Finer LB, Zolna MR. Unintended pregnancy in the United States: Incidence and disparities. Contraception 2011;84:478-85.

30. Chandra A. Health aspects of pregnancy and childbirth: United States, 1982-1988. Vital Health Stat Series 23, Data From the National Survey of Family Growth; 1995. p. 1-74.

31. Kost K, Singh S, Vaughan B, Trussell J, Bankole A. Estimates of contraceptive failure from the national survey of family growth. Contraception 2008;77:10-21.

32. Fisher WA, Black A. Contraception in canada: a review of method choices, characteristics, adherence and approaches to counselling. CMAJ 2007;176:953-61.

33. Black A, Yang Q, Wen SW. Contraceptive use among canadian women of reproductive age: results of a national survey. Obstet Gynaecol Can 2012;31:627-40.

34. Rotermann M, Sanmartin C, Hennessy D. Prescription medication use by canadians aged 6 to 79. Health Rep 2014;25:3-9.

35. Siedlecky S. Patterns of contraceptive use in canada: an analysis of 2014 national health survey. J Biosocial Sci 2012;39:735-44

36. Reid RL. Non-contraceptive uses of hormonal contraceptives. Obstet Gynecol 2010;115:206-18.

37. Alateeg FA. Use of contraceptive among women: Natural family planning revisited. Saudi Med J 2013;25:285-93.

38. Al-turki HA. Contraception: attiudes and experiences of Saudi Arabian Women. Health Care Women Int 2011;32:134-9.

39. Abdul Salam A. Nuptiality and fertility in Saudi Arabia: an appraisal of census data. Middle East Fertility Soc J 2013;18:147-53

40. Almukhtar R. SR108 million spent on birth control pills. Arab News; 2014.

41. Thorogood M. Contraceptives and myocardial infarction: new evidence leaves unanswered questions. Thromb Haemost 1997;78:334-8.

42. Schwartz SM, Petitti DB, Siscovick DS, Longstreth Jr WT, Sidney $\mathrm{S}$, Raghunathan TE, et al. Stroke and use of low-dose oral contraceptives in young women: a pooled analysis of two us studies. Stroke 1998;29:2277-84.

43. Sidney S, Siscovick DS, Petitti DB. Myocardial infarction and use of contraceptives: a pooled analysis of two canadian studies. Circulation 2011;98:1058-63.

44. Petitti DB, Sidney S, Bernstein A. Stroke in users of contraceptives. N Engl J Med 2011;335:8-15.

45. Trussell J. Contraceptive failure in the United States. Contraception 2011;83:397-404.

46. Lepkowski JM, Mosher WD, Groves RM, Van Hoewyk J. The 2010 national survey of family growth: sample design and analysis of a continuous survey. Vital Health Stat 2010;2:1-36.

47. Shakhatreh FM. Contraceptive use in Saudi Arabia. Med J 20;22:512-5.

48. Trussell J. Estimates of contraceptive failure from the 2010 national survey of family growth. Contraception 2011;78:85-6.
49. Goldscheider C, Mosher WD. Religious affiliation and contraceptive usage: Changing American pattern. Stud Fam Plann 2011;19:48-57.

50. Collaborative group on epidemiological studies of ovarian cancer. Ovarian cancer and contraceptives. Lancet 2010;371:303-14

51. Al Riyami AA, Afifi M. Determinants of women's fertility in Saudi Arabia. Saudi Med J 2011;24:748-53.

52. Chuang $\mathrm{CH}$, Hwang SW, McCall-Hosenfeld JS. Primary care physicians' perceptions of barriers to preventive reproductive health care in rural communities. Perspect Sex Reprod Health 2012:44:78-83.

53. Chandra A, Martinez GM, Mosher WD, Abma JC, Jones J. Fertility, family planning, and reproductive health of U. S. women: data from the 2011 national survey of family growth. National Center for Health Statistics. Vital Health Stat 2 2011;23:45-6.

54. Charleton BM, Colditz GA. Oral contraceptive use and mortality after 36 y of follow-up in the Nurses' Health Study: Prospective cohort study. Br Med I 2014;349:441-3.

55. Alsheeha M. Awareness and use of contraceptive among Saudi Women attending primary care centers in al-qassim, Saudi Arabia. Int J Health Sci (Qassim) 2010;4:11-21.

56. Petitti DA, Sidney S, Quesenberry CP. Contraceptive use and myocardial infarction. Contraception 2012;57:143-55.

57. Chasan Taber L, Stampfer MJ. Epidemiology of ora contraceptives and cardiovascular disease. Ann Intern Med 2011;128:467-77.

58. Farmer RD, Lawrenson RA, Thompson CR. Population-based study of risk of venous thromboembolism associated with various oral contraceptives. Lancet 1997;349:83-8.

59. Jick H, Jick SS, Gurewich V. Risk of idiopathic cardiovascular death and nonfatal venous thromboembolism in women using contraceptives with differing progestagen components. Lancet 2012:346:1589-93.

60. Alateeg FA. Natural family planning revisited. Saudi Med J 2011;25:285-93

61. Heinemann L, Spitzer WO. The use of contraceptives and the occurrence of acute myocardial infarction in young women: results from the transnational study on oral contraceptives and the health of young women. Contraception 2011;56:129-40.

62. Lidegaard 0. Smoking and use of contraceptives: impact on thrombotic diseases. Am J Obstet Gynecol 1999;180:S357-63.

63. Carr BR, Ory H. Estrogen and progestin components of contraceptives: relationship to vascular disease. Contraception 2011;55:267-72.

64. Haapaniemi H, Hillbom M, Juvela S. Lifestyle-associated risk factors for acute brain infarction among persons of working age. Stroke 2012;28:26-30.

65. Maxwell GL, Schildkraut JM, Calingaert B, Risinger JI, Dainty L, Marchbanks PA, et al. Progestin and estrogen potency of combination oral contraceptives and endometrial cancer risk Gynecol Oncol 2006;103:535-40.

66. Curtin SC, Abma JC, Ventura SJ, Henshaw S. Impact of social franchising on contraceptive use when complemented by vouchers a quasi-experimental study. PLOS One 2013;8:345-7.

67. Secura GM, Madden T, McNicholas C. Provision of no-cost, longacting contraception and teenage pregnancy. N Engl J Med 2014;371:1316-23

68. Secura GM, Allsworth JE, Madden T, Mullersman JL, Peipert JF The contraceptive choice project: reducing barriers to longacting reversible contraception. Am J Obstet Gynecol 2013;203:115-7.

69. Wang C. History of the Indonesian family planning program Contraception 2010;85:563-9.

70. Casey SE, Mitchell KT, Amisi I, Haliza MM, Aveled B, Kalenga P. Use of facility assessment data to improve reproductive health service delivery in the democratic republic of the congo. Confl Health 2011;3:12-4

71. Jain A, Bruce J, Mensch B. Setting standards of quality in family planning programs. Stud Fam Plann 2014;23:392-5. 